\title{
Electrocardiogram Category
}

National Cancer Institute

\section{Source}

National Cancer Institute. Electrocardiogram Category. NCI Thesaurus. Code C83254.

A classification of electrocardiogram data. 